\title{
Review of hepatocellular cancer, hypertension and renal impairment as late complications of acute porphyria and recommendations for patient follow-up
}

\author{
Mary Felicity Stewart
}

\begin{abstract}
Correspondence to
Professor Mary Felicity Stewart,

Department of Clinical

Biochemistry, University of

Manchester, Salford Royal NHS

Foundation Trust, Stott Lane,

Salford M6 8HD, UK;

Felicity.stewart@srft.nhs.uk
\end{abstract}

Accepted 9 July 2012

Published Online First

31 July 2012

\section{ABSTRACT}

This review critically appraises the data emerging from small retrospective and prospective cohort studies suggesting that patients with the autosomal dominant acute porphyrias may be at increased risk of hepatocellular cancer $(\mathrm{HCC})$, hypertension $(\mathrm{HT})$ and renal impairment. The most striking finding is a marked excess risk of HCC in Swedish patients with acute intermittent porphyria (AIP). As Sweden has a relatively high prevalence of AIP due to a founder effect, it is uncertain to what extent the finding is generalisable to other populations or other acute porphyrias and whether early intervention through screening can improve outcomes. As yet there is no evidence for the cost-effectiveness of systematic surveillance for HCC in acute porphyria outside Sweden. Data from several populations also suggest a high prevalence of chronic sustained $\mathrm{HT}$ and renal impairment in AIP, but it is uncertain if this represents a true excess risk, in particular for asymptomatic patients. As these long-term complications are important and potentially treatable, a pragmatic recommendation is that symptomatic patients with acute porphyria should be offered specialist long-term follow-up and, for those aged $>50$ years, annual liver ultrasound may be considered following discussion of the likely risks and benefits. Opportunistic cardiovascular risk assessment can readily be incorporated into a structured annual review so that appropriate drugs safe for use in acute porphyria are prescribed promptly. As these diseases are rare, collaborative international epidemiological studies such as those being coordinated through the European Porphyria Network are essential to inform best clinical practice.

\section{INTRODUCTION}

The porphyrias are a family of disorders that each result from a specific enzyme deficiency (inherited or acquired) in the haem biosynthetic pathway. There are three types of autosomal dominant inherited porphyrias that may present with acute neurovisceral attacks: acute intermittent porphyria (AIP), variegate porphyria (VP) and hereditary coproporphyria (HCP). To date, there is a lack of robust epidemiological studies of the incidence and prevalence of these disorders in most countries. The prevalence of the genetic defects in European populations is estimated as 1-2:10000 for AIP, 1:30 000 for VP and <1:50 000 for HCP (personal communication, Dr M Badminton, Cardiff Porphyria Centre). In Sweden the prevalence of AIP is much higher due to a founder effect, with a single common mutation of the hydroxymethylbilane synthase (HMBS) gene, W198X, accounting for more than half the cases. ${ }^{1}$ Similarly, in South Africa, VP has an estimated gene prevalence of 1-2:1000 of the European immigrant population and approximately $95 \%$ carry a single mutation, $\mathrm{R} 59 \mathrm{~W}$, in the protoporphyrinogen oxidase gene. ${ }^{2}$ In contrast, the European population is genetically very heterogeneous with many private mutations identified in AIP, VP and HCP. In all three disorders penetrance is low, so only a minority of patients inheriting a mutation will experience acute attacks which, if not recognised and promptly treated, may be life-threatening and sometimes result in permanent neurological complications.

Accurate methods for diagnostic testing of family members, good education of patients and doctors about known precipitants and more effective modern management are all important factors that nowadays contribute to reduced mortality and morbidity from acute porphyria attacks. Thus, more attention needs to be focused on the potential for long-term complications as the life expectancy of affected patients improves. Since the acute porphyrias are rare diseases there are only a limited number of small, mostly retrospective, studies that address this issue. The most convincing data concern hepatocellular cancer (HCC), hypertension (HT) and renal impairment, and these studies are reviewed in this paper.

\section{PRIMARY HEPATOCELLULAR CANCER (HCC) IN ACUTE PORPHYRIA \\ Acute intermittent porphyria (AIP)}

The first reports of a link between AIP and HCC appeared in 1984 from the Swedish population. ${ }^{3}{ }^{4}$ Several subsequent analyses of Finnish, Swedish and Danish patient populations have provided further evidence of a substantially increased incidence of HCC relative to expected rates in the general population. ${ }^{5-9}$ The extent of overlap of subjects included in this series of studies is not clear. One retrospective study of mortality in a US population of 136 patients with AIP over a 50-year period did not identify any cases of HCC, but follow-up data were not available in $22 \%$ of this cohort..$^{10}$ An increased incidence of HCC has also been reported for patients with AIP in a larger prospective study in France. ${ }^{11}$ In Switzerland, two cases of HCC occurred among 205 subjects with AIP diagnosed during a 15 -year period. ${ }^{12} \mathrm{~A}$ recent prospective study of the incidence of HCC in 
acute porphyria in five European countries identified 14 new cases (11 AIP, 3VP) over a 3-year period. Eleven of these patients were from Sweden, including four patients with latent AIP, giving a 63-fold greater incidence per million inhabitants of this complication of AIP in Sweden than in the other countries (France, Netherlands, Switzerland, UK) (unpublished data from the European Porphyria Network project supported by the European Commission DGSANCO, 2012).

While the absolute numbers of HCC cases in each of these studies are small, where calculated, the differences between the expected and observed incidence rates are striking (table 1).

In addition to the cohort studies, individual case reports linking AIP and HCC have been published ${ }^{13-16}$ but at least some of these subjects may also have been included in other publications.

Importantly, HCC appears to occur in patients with and without evidence of liver cirrhosis ${ }^{17}$ and, in the French series, the tumours were associated with factors such as encapsulation, favouring successful resection. ${ }^{11}$ In the most recent Swedish report, ${ }^{9}$ cirrhosis was rarely present among the 22 patients with HCC identified during the prospective study period and there was no evidence that other risk factors such as alcohol or viral hepatitis were implicated. There was a female preponderance and 73\% of the AIP gene carriers developing HCC had experienced previous acute porphyria attacks. This study was conducted in a region with an exceptionally high background prevalence of AIP with a predominant single founder mutation (W198X).

The mechanism of carcinogenesis in AIP is unknown. Hypotheses proposed include direct carcinogenicity of aminolaevulinic acid (ALA), reduced scavenging of free radicals due to reduced haem-containing antioxidant enzymes in liver cells and direct or indirect effects of HMBS mutations on transcription of tumour suppressor genes. ${ }^{11}{ }^{16-19}$ As the total numbers of cases are so small, no relationship between increased HCC risk and particular HMBS mutations has been demonstrated to date.

\section{Variegate porphyria (VP)}

Evidence linking HCC to VP is more limited. Most cohort studies published to date have identified only single cases. There is a small number of published case reports, ${ }^{20-22}$ but some are the individuals identified in the cohort studies. In at least one published case VP was only diagnosed because of the development of skin lesions in a patient presenting with advanced HCC. The Finnish series included 61 patients with VP, of whom one died of HCC. ${ }^{6}$ In contrast, seven cases of HCC were identified in 145 patients with AIP in this study. In the French prospective series, one case of HCC occurred in a population of 136 patients with VP during the follow-up period compared with five cases from 430 patients with AIP. $^{11}$ A report from Switzerland has identified two cases among 37 patients diagnosed with VP. ${ }^{12}$ It is notable that no link between VP and HCC has been reported from the South African population where there is a relatively high prevalence of the disease.

\section{Hereditary coproporphyria (HCP)}

There is a single case report of HCC occurring in association with $\mathrm{HCP}^{23}$ The same authors identified one patient with

Table 1 Summary of studies reporting risk of HCC in acute porphyria

\begin{tabular}{|c|c|c|c|c|c|c|c|}
\hline \multirow[b]{2}{*}{ Reference } & \multirow[b]{2}{*}{ Study type } & \multirow[b]{2}{*}{ Population } & \multirow[b]{2}{*}{ Subjects } & \multicolumn{4}{|c|}{ HCC cases } \\
\hline & & & & Total & Men & Women & Comments \\
\hline $\begin{array}{l}\text { Lithner and } \\
\text { Wetterberg }^{3}\end{array}$ & Retrospective & Sweden & & 11 & 4 & 7 & 5 had cirrhosis \\
\hline Hardell et al ${ }^{4}$ & Case-control & Sweden & 83 men with HCC & 3 & 3 & 0 & $\begin{array}{l}3 / 83 \text { men with HCC had a previous diagnosis of AIP } \\
\text { vs no control }\end{array}$ \\
\hline $\begin{array}{l}\text { Bengtsson and } \\
\text { Hardell }^{13}\end{array}$ & Retrospective & Sweden & $\begin{array}{l}2 \text { families (15 AIP } \\
\text { subjects) }\end{array}$ & 5 & 3 & 2 & \\
\hline $\begin{array}{l}\text { Kauppinen and } \\
\text { Mustajoki }^{5}\end{array}$ & Retrospective cohort & Finland & $\begin{array}{l}245 \text { patients (184 AIP; } 61 \\
\text { VP); } 163 \text { living; } \\
82 \text { deceased }\end{array}$ & 7 & 5 & 2 & $\begin{array}{l}6 \text { AIP, } 1 \text { VP, all deceased. } \\
\text { No data on } 39 / 163(24 \%) \text { of living subjects, } \\
61 \text {-fold increased risk (compared to general } \\
\text { population) }\end{array}$ \\
\hline $\begin{array}{l}\text { Kauppinen and } \\
\text { Mustajoki }^{6}\end{array}$ & Retrospective cohort & Finland & $\begin{array}{l}268 \text { patients in disease } \\
\text { register: } 206 \text { in follow-up } \\
\text { group }\end{array}$ & 8 & 6 & 2 & $\begin{array}{l}\text { 7AIP, } 1 \text { VP, all deceased (includes same cases as } \\
\left.\text { reference }{ }^{5}\right) \text {. } \\
\text { No data on } 62(23 \%) \text { of follow-up group }\end{array}$ \\
\hline $\begin{array}{l}\text { Andersson } \\
\text { et } a l^{7}\end{array}$ & $\begin{array}{l}\text { Retrospective } \\
\text { population-based mortality } \\
\text { study }\end{array}$ & Sweden & $\begin{array}{l}33 \text { AIP subjects in } 2122 \\
\text { deceased subjects }\end{array}$ & 9 & 3 & 6 & $\begin{array}{l}\text { Among } 9 \text { HCC cases, } 2 \text { had cirrhosis, } \\
3 \text { 'pre-cirrhosis', } 3 \text { not possible to assess. } \\
27 \% \text { risk of HCC in AIP vs } 0.2 \% \text { in general } \\
\text { population }\end{array}$ \\
\hline Bjersing et $a l^{17}$ & $\begin{array}{l}\text { Retrospective } \\
\text { case series }\end{array}$ & Sweden & $\begin{array}{l}22 \text { patients with AIP and } \\
\text { HCC }\end{array}$ & 17 & 7 & 10 & $\begin{array}{l}\text { Morphological and genetic data available for 17/22 } \\
\text { subjects ( } 3 \text { latent, } 14 \text { overt AIP) }\end{array}$ \\
\hline Jeans et $a l^{10}$ & $\begin{array}{l}\text { Retrospective cohort study } \\
\text { ( } 50 \text { years cumulative } \\
\text { mortality) }\end{array}$ & USA & 168 AIP patients & 0 & 0 & 0 & $\begin{array}{l}50 \text { deceased; no HCC cases; } \\
\text { no data on } 32(19 \%)\end{array}$ \\
\hline Linet et $a l^{8}$ & $\begin{array}{l}\text { Prospective cohort: Sweden } \\
\text { 1965-1983; Denmark } \\
\text { 1977-1989 }\end{array}$ & $\begin{array}{l}\text { Sweden } \\
(n=231) \\
\text { Denmark } \\
(n=65)\end{array}$ & 296 AIP patients & 5 & NS & NS & $\begin{array}{l}\text { All HCC cases Swedish; SIR } 70.4 \text { (95\% CI } 22.7 \text { to } \\
\text { 164.3) }\end{array}$ \\
\hline Andant et $a l^{11}$ & $\begin{array}{l}\text { Prospective cohort 1989- } \\
1996\end{array}$ & France & $\begin{array}{l}650 \text { patients ( } 430 \text { AIP; } \\
136 \text { VP; } 84 \text { HCP); }\end{array}$ & 7 & 4 & 3 & $\begin{array}{l}5 \text { AIP, 1VP, } 1 \text { HCP. Overall SIR } 36 \text { (95\% CI } 14 \text { to } 74) \text {, } \\
26(95 \% \text { CI } 8 \text { to } 59) \text { after excluding } 2 \text { AIP patients } \\
\text { with cirrhosis and viral hepatitis } \\
\text { (no data on } 71(11 \%))\end{array}$ \\
\hline $\begin{array}{l}\text { Schneider Yin } \\
\text { et } a l^{12}\end{array}$ & $\begin{array}{l}\text { Retrospective cohort } \\
\text { 1993-2007 }\end{array}$ & Switzerland & 205 AIP; 37 VP; 4 HCP & 4 & 0 & 4 & 2 AIP, 2 VP. SIR not calculated \\
\hline $\begin{array}{l}\text { Innala and } \\
\text { Andersson }\end{array}$ & $\begin{array}{l}\text { Prospective cohort 1994- } \\
2009\end{array}$ & $\begin{array}{l}\text { Northern } \\
\text { Sweden }\end{array}$ & $\begin{array}{l}180 \text { AIP gene carriers } \\
\text { age }>55 \text { years }\end{array}$ & 22 & 12 & 10 & SIR 64 (95\% CI 40 to 97$)$ \\
\hline
\end{tabular}

AIP, acute intermittent porphyria; HCC, hepatocellular cancer; HCP, hereditary coproporphyria; SIR, standardised incidence ratio; VP, variegate porphyria. 
HCP and HCC in the prospective French study, ${ }^{11}$ although it is not absolutely clear if this is the same individual.

In summary, a significantly increased risk of HCC has been demonstrated for patients with AIP in prospective cohort studies from Scandinavian and French populations which is particularly marked in the Swedish population. A similar increased risk cannot be ruled out for other populations or other acute porphyrias, although the evidence is much weaker with more limited numbers of cases being identified in association with VP and only one with HCP.

\section{Screening for HCC in patients with acute porphyria}

The emergence of reports linking HCC with acute porphyria (mainly AIP) have led some porphyria experts to propose surveillance of all acute porphyria gene carriers aged $>50$ years and, conversely, that evidence of an underlying acute porphyria should be sought in any patient presenting with HCC in the absence of cirrhosis. ${ }^{24}$

The answers to the following questions are unknown for most European populations:

- Is the natural history of HCC in acute porphyria influenced by early diagnosis?

- What are the risks and benefits of any proposed screening method in patients with asymptomatic and overt acute porphyria?

Given the rarity of acute porphyria, these questions are likely to remain unanswered and it is necessary to extrapolate from other data to make pragmatic recommendations.

In other settings, resection of early HCC lesions detected through surveillance is reported to have a good prognosis, ${ }^{25}$ and UK clinical guidelines recommend routine surveillance for HCC among individuals with cirrhosis. ${ }^{26}$ In drawing comparisons, it should be remembered that the pathology of HCC in acute porphyria may be very different, given the apparent lack of association with prior cirrhosis.

The optimal screening strategy for HCC in other high-risk conditions remains under debate. A UK evaluation of a variety of surveillance algorithms using serum $\alpha$-fetoprotein (AFP) and/or ultrasound at 6- and 12-monthly intervals in a mixed aetiology cohort suggests that such surveillance is both clinically effective and cost-effective, although the economic efficiency in patients with prior cirrhosis is predicted to vary markedly with the aetiology. ${ }^{27}$

Following the recognition of the unexpectedly high incidence of HCC in patients with AIP in Sweden, surveillance of AIP gene carriers aged $>55$ years was introduced in one county in Northern Sweden in 1994. Improved 3-year and 5-year survival was reported in patients who participated in screening at intervals of $1-1.5$ years compared with those who did not. ${ }^{9}$ These authors comment that lead time bias may have influenced their results. They also state that AFP was not helpful and recommend liver ultrasound as a first-line screening test.

Although this is an important study, it must be acknowledged that the benefits of early diagnosis through systematic surveillance remain speculative in other more genetically heterogeneous populations with a lower background prevalence of acute porphyria and incidence rates of HCC. It must also be recognised that any form of screening has the potential to do harm, for example, by causing anxiety to otherwise asymptomatic individuals and the generation of false positive screening tests.

\section{HYPERTENSION (HT) AND RENAL IMPAIRMENT IN ACUTE PORPHYRIA}

Several case series and cohort studies (mostly retrospective) propose that there is an increased risk of chronic sustained HT and renal failure in patients with acute porphyria. ${ }^{28-33}$ Almost all the available data relate to AIP (table 2). Within these studies, small numbers of other renal diseases such as diabetes, polycystic kidneys and systemic lupus erythematosus have also occurred coincidentally.

The definitions of HT and methods for identifying renal impairment differ between studies. Andersson et al defined HT based on the prescription of any antihypertensive drug and, in the later population-based study, assessed both creatinine clearance and chromium EDTA clearance as measures of glomerular filtration rate. ${ }^{3132}$ Others have used differing cut-off values for blood pressure and a variety of measures of renal function or merely reported clinical diagnoses or recorded deaths due to renal failure. This imposes a serious limitation on the validity of combining data from these studies

Chronic HT is undoubtedly a common accompaniment to AIP, particularly those with overt disease. However, it is also common in the general population. In the case-control study by Andersson et al, HT was significantly increased in overt AIP relative to controls and latent AIP (defined as those who had never had symptoms). ${ }^{31}$ Patients with latent AIP did not differ significantly from their controls ( $28 \%$ of whom had HT). In a retrospective Finnish cohort, HT was higher than the expected rate in the non-porphyric population, but only in certain age groups (table 2).

Some studies have reported higher than expected rates of renal failure (including deaths from this cause), but this is not a consistent finding. This may be due to differences in ascertainment or small numbers of cases (table 2).

There are a number of individual case reports describing renal transplantation in patients with AIP. ${ }^{33-36}$ A variety of morphological lesions have been reported in renal biopsies from AIP subjects with renal failure. These include both glomerular sclerosis and tubulointerstitial nephritis. In some studies, evidence of analgesic nephropathy was specifically sought but not confirmed. One recent study examined renal biopsies in nine AIP patients with renal impairment without $\mathrm{HT}$ and found no glomerular lesions but tubulointerstitial nephritis. ${ }^{37}$

Proposed mechanisms for the renal damage include ischaemic insults due to vasospasm during acute attacks, nephrotoxicity of ALA or other porphyrin intermediates and the effects of sustained chronic $\mathrm{HT}^{32} 37$

In summary, chronic sustained HT is prevalent in AIP and some studies have reported an increased risk of chronic renal impairment leading to end-stage renal failure. There is a paucity of data for other forms of acute porphyria. The risk of renal failure may be correlated with the occurrence of HT during acute attacks. Despite the high prevalence of chronic HT, the available studies have not demonstrated an increased risk of cardiovascular mortality. As the background risk of both HT and cardiovascular disease in the population is high, accurate detection of the true excess risk in patients with acute porphyria is difficult.

Opportunistic screening for modifiable cardiovascular risk factors such as blood pressure and reduced estimated glomerular filtration rate is essentially non-controversial and has been widely adopted in many other clinical groups. Treatment of these risk factors is no less likely to confer benefit for patients with acute porphyria provided that only drugs identified as safe for use in acute porphyria are prescribed.

\section{CRITICAL APPRAISAL SUMMARY}

The studies available to date are principally cohort studies, case-control studies and case series, corresponding to evidence 
Table 2 Summary of studies linking acute porphyria with HT and renal impairment

\begin{tabular}{|c|c|c|c|c|}
\hline Reference & Study type & Population & Subjects & Comments \\
\hline $\begin{array}{l}\text { Beattie and } \\
\text { Goldberg }^{28}\end{array}$ & Retrospective cohort (20-year period) & UK & $\begin{array}{l}38 \text { AIP patients with previous } \\
\text { attacks }\end{array}$ & $\begin{array}{l}\text { Diastolic } \mathrm{BP}>100 \mathrm{~mm} \mathrm{Hg} \text { in } 50 \% ; 1 \text { death due to early onset CRF } \\
\text { and malignant } \mathrm{HT} ; 3 \text { deaths due to complications of HT }\end{array}$ \\
\hline Laiwah et $a l^{29}$ & $\begin{array}{l}\text { Retrospective } \\
\text { case series }\end{array}$ & Scotland & $\begin{array}{l}6 \text { AIP patients with previous } \\
\text { attacks identified with chronic } \\
\text { renal failure and sustained HT }\end{array}$ & $\begin{array}{l}\text { Observed vs expected CRF prevalence } 6 \text { vs } 65 \text { in AIP cases (in } \\
\text { remission but with previous acute attacks) compared with } 52 \text { per } \\
\text { million in general population }\end{array}$ \\
\hline Church et $\left.a\right|^{30}$ & $\begin{array}{l}\text { Prospective and retrospective case } \\
\text { series (within single kindred) }\end{array}$ & UK & 26 AIP and 26 non-AIP subjects & $\begin{array}{l}\text { Overall in AIP subjects, } 62 \% \text { had HT, } 50 \% \text { had renal impairment; } \\
5 \text { deaths directly related to HT (of whom } 3 \text { had renal failure) }\end{array}$ \\
\hline $\begin{array}{l}\text { Kauppinen and } \\
\text { Mustajoki }^{6}\end{array}$ & Retrospective cohort & Finland & $\begin{array}{l}268 \text { patients in disease register, } \\
206 \text { in follow-up group. No data } \\
\text { on } 62(23 \%)\end{array}$ & $\begin{array}{l}\text { HT and renal failure prevalence higher than general population in } \\
\text { some age groups: } \\
\text { HT: } 12 \%(n=5) \text { vs } 3.3 \% \text { in women aged } 30-44 \text { years }(p=0.03) \\
56 \%(n=5) \text { vs } 19 \% \text { in men aged } 55-64 \text { years }(p=0.03) \\
\text { Renal failure: } 9 \text { subjects }(5.7 \%) \text { overall. } 7 \%(n=3) \text { vs } 0.07 \% \text { of } \\
\text { women aged } 30-44 \text { years }(p=0.0002) \text { and } 9.5 \%(n=2) \text { vs } 0.37 \% \\
\text { of women aged } 45-54 \text { years }(p=0.01) .4 \text { deaths due to renal } \\
\text { failure }\end{array}$ \\
\hline $\begin{array}{l}\text { Andersson } \\
\text { et } a l^{31}\end{array}$ & $\begin{array}{l}\text { (1) Case-control study; }(2) \\
\text { retrospective mortality study (12-year } \\
\text { period); (3) case series }\end{array}$ & Sweden & $\begin{array}{l}\text { (1) } 50 \text { AIP ( } 25 \text { overt; } 25 \text { latent) } \\
\text { with } 200 \text { matched controls; } \\
\text { (2) } 2122 \text { deceased subjects ( } 33 \\
\text { with AIP); } \\
\text { (3) } 8 \text { AIP patients with severe } \\
\text { recurrent attacks }\end{array}$ & $\begin{array}{l}\text { (1) HT in } 56 \% \text { of patients with overt AIP, } 33 \% \text { of controls } \\
\text { ( } p=0.041) \text { and } 16 \% \text { with latent AIP }(p=0.004) \text {. No difference in } \\
\text { renal disease (AIP vs controls) } \\
\text { (2) HT registered in } 13 / 19(68 \%) \text { with overt AIP and } 3 / 14(21 \%) \\
\text { with latent AIP ( } p=0.008 ; \text { OR } 7.9) \text {. Death from MI or stroke was } \\
\text { not more common than in non-AIP patients } \\
3 / 33(9.1 \%) \text { AIP patients died from uraemia vs } 22 / 2089 \text { without } \\
\text { AIP }(1 \%)(p=0.006 \text {; OR } 9.4) \\
\text { (3) } 3 / 8 \text { severe AIP cases had renal impairment ( } 1 \text { due to SLE) }\end{array}$ \\
\hline Jeans et $a l^{10}$ & $\begin{array}{l}\text { Retrospective cohort study of } \\
\text { cumulative mortality over a } 50 \text {-year } \\
\text { period }\end{array}$ & USA & $\begin{array}{l}168 \text { AlP patients; } \\
\text { no data on } 32(19 \%)\end{array}$ & $\begin{array}{l}72 / 136 \mathrm{HT} ; \\
53 / 136 \text { 'azotemia BUN }>25 \mathrm{mg} / \mathrm{dl})^{\prime} ; \\
\text { SIR not calculated. } 1 \text { death due to renal failure }\end{array}$ \\
\hline $\begin{array}{l}\text { Andersson } \\
\text { et } a l^{32}\end{array}$ & Population-based & Sweden & $\begin{array}{l}\text { 286/386 eligible patients with AIP } \\
\text { screened for low } \mathrm{CrCl}\end{array}$ & $\begin{array}{l}34 / 286(12 \%) \text { had } \mathrm{CrCl}<65 \mathrm{ml} / \mathrm{min} \text { per } 1.73 \mathrm{~m}^{2} \text {; } \\
\text { AIP was sole explanation in } 16.12 / 16 \text { had } \mathrm{HT}\end{array}$ \\
\hline Marsden et $a l^{37}$ & Case series & UK & 9 patients with AIP and CRF & HT and NSAIDs were contributory factors in $~ 50 \%$ \\
\hline
\end{tabular}

AIP, acute intermittent porphyria; BUN, blood urea nitrogen; CrCl, creatinine clearance; CRF, chronic renal failure; HT, hypertension; MI, myocardial infarction; NSAIDs, non-steroidal

anti-inflammatory drugs; SIR, standardised incidence ratio; SLE, systemic lupus erythematosus.

Levels $2 b, 3 b$ and 4 , respectively, according to the hierarchy defined by the Oxford Centre for Evidence-Based Medicine. ${ }^{38}$

In assessing this literature, the following points have been considered:

1. The populations are mostly well-defined and characterised with respect to porphyria diagnosis.

2. In three prospective studies the follow-up periods were between 7 and 18 years and data were complete for $>86 \%$ of eligible subjects.

3. Absolute numbers of patients identified with HCC are small. Confounding risk factors such as alcohol and viral hepatitis were considered in some but not all of the studies.

4. Definitions of HT and renal impairment are not consistent between studies. Confounding risk factors such as alcohol, weight and smoking have not been systematically addressed in all studies.

5. Combination of data from all the studies may not be valid as the extent of overlap of individual subjects included in sequential publications from the same authors is unclear.

6. Selection bias (systematic error) in identifying cohort groups cannot be excluded; for example, patients attending porphyria centres may have different characteristics from those managed in non-specialist settings.

7. The results from populations that are relatively genetically homogeneous (eg, Sweden) may not be generalisable to other more heterogeneous populations (eg, the UK).

\section{RECOMMENDATIONS}

- Currently there is no evidence that screening for HCC in patients with acute porphyria (whether overt or asymptomatic) is likely to be cost-effective in any country other than Sweden.
- Clinicians should be aware of the reports of HCC as a late complication of acute porphyria and should consider this diagnosis in the following circumstances:

- in any patient with acute porphyria with unexplained abnormal liver function tests or symptoms and signs suggestive of underlying liver disease or malignancy;

- in patients who develop manifestations of acute porphyria (skin lesions or acute attacks) after the age of 50 years, particularly for the first time or after a period of latency.

- Periodic (annual) ultrasound should be considered for individuals aged $>50$ years with previous overt or asymptomatic disease who ask to be tested after careful discussion of the likely risks and benefits.

- Available evidence does not support screening for renal complications in asymptomatic acute porphyria gene carriers.

- Measurement of blood pressure, estimated glomerular filtration rate and proteinuria (early morning spot urine albumin: creatinine or protein:creatinine ratio) should be incorporated as part of the annual structured review of adult patients followed up because of previous or current overt acute porphyria.

- Management of HT should follow a treatment algorithm modified to use agents known to be safe in acute porphyria. Similar considerations apply to the management of other cardiovascular risk factors that may be identified, such as hyperlipidaemia.

- If progressive renal impairment (with or without proteinuria) is identified, local guidelines for risk factor management and referral to renal services should be followed, adopting a shared care approach, so that special factors relevant to the management of acute porphyria are considered (particularly in relation to prescribing). 


\section{CONCLUSIONS}

The data presented have acknowledged limitations but draw attention to important late complications of acute porphyria, supporting the provision of specialist long-term follow-up to detect and treat these effectively. As with other rare diseases, there are genuine difficulties in applying tools such as large-scale evaluations of formal screening programmes. Resources available to provide systematic ascertainment and specialist long-term follow-up of patients with acute porphyria differ markedly, even in highly developed European healthcare systems. There is an urgent and ongoing need to improve our understanding of the evolving natural history of acute porphyria and to clarify the influence of genotype on long-term outcomes. This is most likely to be achieved by international collaboration in epidemiological studies and the development of disease registers such as those planned by the European Porphyria Network. ${ }^{39}$

\section{KEY MESSAGES}

- An excess risk of hepatocellular cancer in acute porphyria has been reported in several European populations, particularly marked in Swedish patients with acute intermittent porphyria (AIP)

- Hypertension and chronic renal impairment are also reported as late complications of AIP

- The true excess risk of these complications in all patient populations and other types of acute porphyria is uncertain, emphasising the need for collaborative epidemiological studies in these rare conditions

Acknowledgements The author thanks Professor George Elder, Emeritus Professor, University of Cardiff, who provided data from the DGSANCO European Porphyria Network project and invaluable advice; and Mr John Chamberlayne (Chair, British Porphyria Association) who provided comments on behalf of patient stakeholders.

Collaborators This manuscript has been prepared on behalf of the clinical subgroup of the British and Irish Porphyria Network (BIPNET; www.bipnet.org.uk): Dr M Badminton, Department of Medical Biochemistry and Immunology, University Hospital of Wales, Cardiff;

Dr J Barth, Department of Clinical Chemistry, Leeds General Infirmary,

Leeds; Dr V Crowley, Irish Porphyria Specialist Centre, St James Hospital, Dublin, Eire; Dr D Rees, Department of Haematology, King's College Hospital, London; Dr P Stein, Department of Medicine, Addenbrooke's Hospital, Cambridge.

\section{Competing interests None.}

Provenance and peer review Commissioned; externally peer reviewed.

\section{REFERENCES}

1. Lundin G, Lee JS, Thunell S, et al. Genetic investigation of the porphobilinogen deaminase gene in Swedish acute intermittent porphyria families. Hum Genet 1997;100:63-6.

2. Meissner PN, Dailey TA, Hift RJ, et al. A R59W mutation in human protoporphyrinogen oxidase results in decreased enzyme activity and is prevalent in South Africans with variegate porphyria. Nat Genet 1996;13:95-7.

3. Lithner F, Wetterberg L. Hepatocellular carcinoma in patients with acute intermittent porphyria. Acta Med Scand 1984;215:271-4.

4. Hardell L, Bengtsson NO, Jonsson U, et al. Aetiological aspects on primary liver cancer with special regard to alcohol, organic solvents and acute intermittent porphyria — an epidemiological investigation. Br J Cancer 1984;50:389-97.

5. Kauppinen R, Mustajoki P. Acute hepatic porphyria and hepatocellular carcinoma Br J Cancer 1988;57:117-20.

6. Kauppinen R, Mustajoki P. Prognosis of acute porphyria: occurrence of acute attacks, precipitating factors, and associated diseases. Medicine (Baltimore) 1992;71:1-13.
7. Andersson C, Bjersing L, Lithner F. The epidemiology of hepatocellular carcinoma in patients with acute intermittent porphyria. J Intern Med 1996;240:195-201.

8. Linet MS, Gridley G, Nyrén 0, et al. Primary liver cancer, other malignancies, and mortality risks following porphyria: a cohort study in Denmark and Sweden. Am J Epidemiol 1999;149:1010-5.

9. Innala $\mathbf{E}$, Andersson C. Screening for hepatocellular carcinoma in acute intermittent porphyria: a 15 year follow up in Northern Sweden. J Intern Med 2011;269:538-45.

10. Jeans JB, Savik K, Gross CR, et al. Mortality in patients with acute intermittent porphyria requiring hospitalisation: a United States case series. Am J Med Genet 1996;65:269-73.

11. Andant C, Puy H, Bogard C, et al. Hepatocellular carcinoma in patients with acute hepatic porphyria: frequency of occurrence and related factors. $J$ Hepatol 2000;32:933-9.

12. Schneider-Yin X, Harms J, Minder El. Porphyria in Switzerland, 15 years' experience. Swiss Med Wkly 2009;139:198-206.

13. Bengtsson NO, Hardell L. Porphyrias, porphyrins and hepatocellular carcinoma. $\mathrm{Br} J$ Cancer 1986;54:115-17.

14. Thunnissen PL, Meyer J, de Koning RW. Acute intermittent porphyria and primary liver cell carcinoma. Neth Med J 1991;38:171-4.

15. Gubler JG, Bargetzi MJ, Meyer UA. Primary liver carcinoma in two sisters with acute intermittent porphyria. Am J Med 1991;91:102-3.

16. Dean G, Freestone M, van den Berg JP, et al. Primary liver cancer in two sisters living in Holland with acute intermittent porphyria. S Afr Med J 1997;87:731-2.

17. Bjersing L, Andersson C, Lithner F. Hepatocellular carcinoma in patients from Northern Sweden with acute intermittent porphyria: morphology and mutations. Cancer Epidemiol Biomarkers Prev 1996;5:393-7.

18. del C Batlle AM. Porphyrins, porphyrias, cancer and photodynamic therapy-a model for carcinogenesis. J Photochem Photobiol B:Biol 1993;20:5-22.

19. Onuki J, Teixeira PC, Medeiros $\mathrm{MH}$, et al. Is 5-aminolevulinic acid involved in the hepatocellular carcinogenesis of acute intermittent porphyria? Cell Mol Biol (Noisy-le-grand) 2002;48:17-26.

20. Tidman MJ, Higgins EM, Elder GH, et al. Variegate porphyria associated with hepatocellular carcinoma. Br J Dermatol 1989;121:503-5.

21. Germanaud J, Luthier $F$, Causse $X$, et al. A case of association between hepatocellular carcinoma and porphyria variegata. Scand J Gastroenterol 1994;29:671-2.

22. Schneider-Yin $\mathbf{X}$, Van Tuyll A-M, Went $\mathrm{P}$, et al. Hepatocellular carcinoma in variegate porphyria: a serious complication. Acta Derm Venereol 2010;90:512-15.

23. Andant C, Puy H, Deybach JC, et al. Occurrence of hepatocellular carcinoma in a case of hereditary coproporphyria. Am J Gastroenterol 1997;92:1389-90.

24. Deybach J-C, Puy H. Hepatocellular carcinoma without cirrhosis: think acute hepatic porphyrias and vice versa. J Intern Med 2011;269:521-4.

25. De Masi S, Tosti ME, Mele A. Screening for hepatocellular carcinoma. Dig Liver Dis 2005;37:260-8.

26. Ryder S. Guidelines for the diagnosis and treatment of hepatocellular carcinoma in adults. Gut 2003;52(Suppl III):iii1-8.

27. Thompson Coon J, Rogers G, Hewson P, et al. Surveillance of cirrhosis for hepatocellular carcinoma: a cost-utility analysis. Br J Cancer 2008;98:1166-75.

28. Beattie AD, Goldberg A. Acute intermittent porphyria: natural history and prognosis. In: Doss M Porphyrins in human diseases. Basel: Karger, 1975:245-50.

29. Laiwah AACY, MacTier R, McColl KEL, et al. Early onset chronic renal failure as a complication of acute intermittent porphyria. O J Med 1983;52:92-8.

30. Church SE, McColl KE, Moore MR, et al. Hypertension and renal failure as complications of acute porphyria. Nephrol Dial Transplant 1992;7:986-90.

31. Andersson C, Lithner F. Hypertension and renal disease in patients with acute intermittent porphyria. J Intern Med 1994;236:169-75.

32. Andersson C, Wikberg A, Stegmayr B, et al. Renal symptomatology in patients with acute intermittent porphyria. A population based study. J Intern Med 2000;248:319-25.

33. Nunez DJ, Williams PF, Herrick AL, et al. Renal transplantation for chronic renal failure in acute porphyria. Nephrol Dial Transplant 1987;2:271-4

34. El-Haggan W, Lobbedez T, Ryckelnynck JP, et al. Sirolimus tolerability in a kidney transplant recipient with acute intermittent porphyria. Nephrol Dial Transplant 2002;17:1147.

35. Warholm C, Wilczek $\mathrm{H}$. Renal transplantation in a case of acute intermittent porphyria. J Clin Pharmacol 2003;43:1158-60.

36. Wahlin S, Harper P, Sardh E, et al. Combined liver and kidney transplantation in acute intermittent porphyria. Transp/ Int 2010;23:e18-21.

37. Marsden JT, Chowdhury P, Wang J, et al. Acute intermittent porphyria and chronic renal failure. Clin Nephrol 2008;69:339-46.

38. Centre for Evidence-Based Medicine (CEBM). CEBM levels of evidence. Oxford Centre for Evidence-Based Medicine. 2011. http://www.cebm.net/index.aspx? $0=5653$

39. Deybach J-C, Parker S, Badminton M, et al. European Porphyria Network (EPNET) for information, epidemiological data, quality and equity of service. Orphanet $J$ Rare Dis 2010;5(Suppl 1):P16. 